\title{
Destination Attractiveness and Memorable Travel Experiences in Silk Road Tourism in Uzbekistan
}

\author{
Murodjon Raimkulov ${ }^{1}$, Husanjon Juraturgunov ${ }^{1}$ and Young-joo Ahn ${ }^{1,2, *}$ \\ 1 Department of Hospitality and Tourism Management, Sejong University, Seoul 05006, Korea; \\ Samsung_9695@mail.ru (M.R.); khusanjon9126@gmail.com (H.J.) \\ 2 Tourism Industry Data Analytics Lab (TIDAL), Department of Hospitality and Tourism Management, \\ Sejong University, Seoul 05006, Korea \\ * Correspondence: yjahn@sejong.ac.kr
}

Citation: Raimkulov, M.; Juraturgunov, H.; Ahn, Y.-j.

Destination Attractiveness and

Memorable Travel Experiences in Silk Road Tourism in Uzbekistan.

Sustainability 2021, 13, 2252.

https://doi.org/10.3390/su13042252

Academic Editor: Alastair

M. Morrison

Received: 30 January 2021

Accepted: 16 February 2021

Published: 19 February 2021

Publisher's Note: MDPI stays neutral with regard to jurisdictional claims in published maps and institutional affiliations.

Copyright: (c) 2021 by the authors. Licensee MDPI, Basel, Switzerland. This article is an open access article distributed under the terms and conditions of the Creative Commons Attribution (CC BY) license (https:/ / creativecommons.org/licenses/by/ $4.0 /)$.

\begin{abstract}
This study explored the relationships between destination attractiveness, satisfaction, the sense of reliving, and loyalty among American tourists who had experienced Silk Road tourism in Uzbekistan. In addition, this study investigated the mediating role of the sense of reliving with regard to satisfaction and loyalty. A total of 477 respondents participated and were used for the final analysis. The results suggest that destination attractiveness includes multidimensional constructs consisting of five dimensions, namely, cultural attractiveness, natural attractiveness, the local people and superstructure, infrastructure, and price attractiveness. Cultural attractiveness, the warm hospitality of local people, and the superstructure appear to be the competitive attributes of Silk Road tourism in Uzbekistan affecting tourist satisfaction. Furthermore, the results reveal that tourist satisfaction increases loyalty. A mediating role of the sense of reliving with regard to satisfaction and loyalty was also confirmed. Tourists remember their travel experiences upon returning home, relive Silk Road travel experiences, and demonstrate their behavioral intentions. These findings can provide a deeper understanding of destination attractiveness and memorable experiences for increasing loyalty to destinations related to Silk Road tourism in Uzbekistan.
\end{abstract}

Keywords: destination attractiveness; satisfaction; loyalty; memories; sense of reliving; memorable travel experience; Silk Road tourism; Uzbekistan

\section{Introduction}

Uzbekistan is located in the center of the Eurasian continent and is well-known due to the Great Silk Road, which connects Europe and China [1,2]. The Great Silk Road developed international trade and is a rich historical and cultural attraction with unique traditions and customs [1]. According to the United Nations Educational, Scientific and Cultural Organization (UNESCO), Uzbekistan has an excellent reputation and several world heritage properties and historical and cultural architectural buildings and treasures in ancient Silk Road destinations, such as Samarkand, Bukhara, Khiva, and Shakhrisabz [3]. Four Uzbekistani cities included in the UNESCO World Heritage List (WHL) have become popular tourism sites and experienced an increase in the arrival of international tourists [4]. Moreover, Uzbekistan's abundant natural resources, such as national parks, wilderness areas, and protected nature reserves, are the unique attributes that attract domestic and international tourists [5]. Tourism in Uzbekistan shows considerable potential, as the country offers various types of tourism products and services and distinct destination features [6].

Numerous studies on tourism in Uzbekistan have explored several aspects, such as inbound tourism development and foreign investment [7,8], gastronomy tourism [9], ecotourism [10], destination attractiveness [6], and the destination image of Silk Road tourism [11]. However, previous studies call for research on key components to develop Uzbekistan into a competitive tourism destination for target markets [6]. 
In this regard, destination attractiveness can be a useful theoretical framework [12]. Destination attractiveness is closely related to tourist satisfaction and loyalty [13-15] and can influence tourists' destination choices, needs, and desires [16]. Destination attractiveness is a destination's capacity to attract tourists [17] and may be the most influential motivation for tourists to visit a destination [18]. Competitive destination attributes can enhance destination images and affective emotions toward a destination and memorable travel experiences [19-22]. Although previous research has explored the antecedents and consequences of memorable travel experiences in different contexts [23-30], there is limited research on destination attractiveness and tourists' memorable experiences, as well as behavioral intentions, in various cultural contexts.

Considering this, the purpose of this study was to explore the relationships between destination attractiveness, satisfaction, the sense of reliving, and loyalty among American tourists who have experienced Silk Road tourism in Uzbekistan. In addition, this study examined the role of the sense of reliving in satisfaction and loyalty in the context of Silk Road tourism in Uzbekistan, in an effort to enrich the hospitality and tourism literature. Furthermore, the stimulus-organism-response (SOR) framework was employed for the proposed model. This study provides empirical evidence for the destination attractiveness of Uzbekistan and ability of destinations to attract tourists and increase their satisfaction, which in turn can affect their memorable travel experiences and loyalty. Furthermore, this study enriches the knowledge on international tourists traveling to Uzbekistan and provides insightful theoretical and practical implications for enhancing destination competitiveness and sustainable destination management in the country.

\section{Literature Review}

\subsection{Destination Attractiveness}

Destination attractiveness is defined as "The feelings, beliefs, and opinions that an individual has about a destination's perceived ability to provide satisfaction in relation to his or her special vacation needs" [19] (p. 25). Destination attractiveness and destination competitiveness are interchangeable. Destination competitiveness is related to the capacity of a tourist destination to offer competitive and better products and services to visiting tourists compared to other destinations [31].

Three main streams were established to identify the components of destination attractiveness. First, a general approach was used to identify the dimensions of destination competitiveness, general aspects, and the dynamic forces in destinations [32] and provide comparative results. Second, the resource-based dimensions of destination attractiveness were similarly employed [12]. Finally, a situational approach was adopted to select specific destination attractiveness items that fit different research settings [19].

Previous research on destination attractiveness has highlighted its importance for decades. First, identifying attributes that can attract tourists to destinations is essential [31]. Attraction attributes are associated with motivations [12]. Second, destination attractiveness can be an important indicator for understanding supply and demand aspects [33]. Third, destination attractiveness can provide a deep understanding of target markets and tourists' decision-making processes and help in tourism planning and tourism policy development [34]. Finally, the World Economic Forum (WEF) created the Travel and Tourism Competitiveness Index (TTCI) for evaluating destination competitiveness and performance and reporting on the comparative rankings of 124 countries [35].

The attributes of destination attractiveness may vary, depending on research settings and researchers' approaches $[19,31,33,34,36-40]$. Substantial research has demonstrated the importance of destination attractiveness in different contexts, such as wineries [37], urban tourism [36], national parks [34], and cultural and heritage sites [41].

To achieve the research goals and objectives of this study, six dimensions were examined, namely, cultural attractiveness, natural attractiveness, complementarity, the superstructure, infrastructure, and price attractiveness. The dimensions are based on the tripartite model of destination attractiveness proposed by Gunn [12], which consists of 
three dimensions, that is, the nucleus, tourist belt, and zone of closure. Recently, Boivin and Tanguay [36] used the dimensions for understanding urban tourism and evaluating the performance of two cities in Canada. First, the nucleus refers to core tourist attractions that strongly appeal to tourists, such as natural sites, cultural and historical sites, and museums. Two attributes, namely, cultural attractiveness and natural attractiveness, were selected for the nucleus $[12,36]$. Second, complementarity refers to the entertainment aspect of tourist destinations, such as entertainment, festivals, and MICE (i.e., meeting, incentives, conferences, and exhibitions). Entertainment attributes such as festivals and events were selected for complementarity. The complementarity aspect was considered, but excluded, after the proposed model was tested [12,36]. Third, the tourist belt refers to tourist facilities, such as parks, and public spaces. Superstructure attributes, such as accommodation and host interactions, were selected for the tourist belt $[12,36]$. Furthermore, general urban characteristics (i.e., the urban context) for residents and tourists exist. The urban context refers to public services, transportation, and tourist information [12,36]. Infrastructure and price attractiveness were employed to capture the urban context $[12,36]$.

\subsection{Destination Attractiveness and Satisfaction}

Previous research has demonstrated that the relationship between destination attractiveness and satisfaction is an important indicator for evaluating the quality of destination attributes, improving a poor performance, and enhancing competitive destination brand images [13-15,42-47].

Satisfaction refers to the positive psychological state or emotions resulting from attribute performance responses or evaluations [48]. Tourist satisfaction is an important indicator for understanding tourist experiences in destination attractions [14]. Moreover, tourist satisfaction from different countries should be examined to expand the understanding of tourist behaviors based on their country of origin [42]. As attractiveness depends on the region and superstructure [49], examining destination attractiveness and satisfaction in different tourism destination contexts is necessary.

Previous research has highlighted a positive relationship between travel attractiveness and satisfaction [13,14,42,45]. For example, Kozak [42] examined the different levels of satisfaction with destination attractiveness among various cultural tourist groups. MedinaMuñoz and Medina-Muñoz [45] demonstrated a positive association between wellness tourism attributes and overall satisfaction. Recently, Jeuring and Haartsen [49] investigated the relationship between destination attractiveness, attitude, and satisfaction in Friesland, the Netherlands, around a world heritage area. The results revealed that weather- and nature-related attributes of destination attractiveness, such as weather conditions, natural resources, soft outdoor activities, and sea and beach activities, have a positive relationship with satisfaction among domestic tourists. Therefore, the following hypotheses were proposed:

Hypotheses 1 (H1). Cultural attractiveness has a positive effect on satisfaction.

Hypotheses 2 (H2). Natural attractiveness has a positive effect on satisfaction.

Hypotheses 3 (H3). The superstructure has a positive effect on satisfaction.

Hypotheses 4 (H4). Infrastructure has a positive effect on satisfaction.

Hypotheses 5 (H5). Price attractiveness has a positive effect on satisfaction.

\subsection{Satisfaction and Loyalty}

Customer loyalty is defined as "a deeply held commitment to rebuy or repatronize a preferred product/service consistently in the future, thereby causing repetitive samebrand or same brand set purchasing" (Oliver [50], p. 392). There is substantial empirical evidence for a positive relationship between satisfaction and loyalty, and this supports the notion of satisfaction affecting loyalty [50,51]. Understanding tourist satisfaction associated with the fulfillment of tourists' expectations and needs is important. Moreover, tourist 
satisfaction can be a strong indicator for predicting the intention to revisit and positive recommendations $[13,14,52]$.

Previous research has examined the relationship between tourist satisfaction and behavioral intentions [13-15]. For example, Kozak and Rimmington [14] found that satisfaction increases tourists' intentions to revisit. Moreover, they demonstrated that repeat tourists show a higher level of intention to revisit than first-time visitors. Yolal, Chi, and Pesämaa [53] supported similar results for a positive association between satisfaction and loyalty among first-time and repeat tourists. They revealed a positive relationship between satisfaction and loyalty. Meanwhile, Owusu-Frimpong, Nwankwo, Blankson, and Tarnanidis [15] examined the quality of destination attractiveness, satisfaction, and intention to revisit among tourists visiting Ghana. They demonstrated that tourist satisfaction is positively related to loyalty toward the tourism destination. Therefore, this present study proposed the following hypothesis:

Hypotheses 6 (H6). Satisfaction has a positive effect on loyalty.

\subsection{Sense of Reliving, Satisfaction, and Loyalty}

The sense of reliving refers to individuals' memories of retrieval of important parts (e.g., emotions and episodic memory) of the event (Rubin, Dennis, \& Beckham [54], p. 841) and the conscious recollection of episodic memory (Rubin, Deffler, \& Umanath [55], p. 48). Recently, numerous researchers have proposed the antecedents of the consequences of memorable travel experiences and provided empirical evidence on memorable travel experiences [22-30]. Regarding the association between memorable travel experiences and satisfaction, Manthiou and colleagues [27] explored the relationship between tourism experiences, satisfaction, recollection, and loyalty among theme park visitors. They found a mediating role of satisfaction with regard to tourist experience and recollection. Recollection also exerted a positive effect on loyalty.

Recently, Kim [22] examined the relationship between memorable tourism experiences, a destination's image, satisfaction, and behavioral intentions by analyzing 301 international tourists in Taiwan and found that memorable tourism experiences are positively related to a destination's image, satisfaction, and behavioral outcomes (e.g., intentions to revisit). Unlike previous studies that considered the role of memorable travel experiences or recollection as an antecedent of satisfaction $[27,28,56]$, some scholars suggest that satisfaction positively influences memorable travel experiences and loyalty [30]. The present study examined the mediating role of a sense of reliving with regard to satisfaction and loyalty toward Silk Road tourism destinations. Travelers' satisfaction may affect relived Silk Road travel experiences among tourists because this study collected data from tourists who had visited the Silk Road in Uzbekistan in the past five years, rather than recently. Therefore, the following hypothesis was proposed:

Hypotheses 7 (H7). Satisfaction has a positive effect on the sense of reliving.

Previous research on hospitality and tourism has demonstrated a positive association between memorable travel experiences and loyalty [22-28,30,57,58]. Tourists' memorable experiences enhanced by destination attractiveness can be a powerful motivation and influence their intentions to revisit a destination [21,22]. Moreover, previous research has explored the effects of memorable experiences on positive behavioral intentions [23,26-28,30]. For example, Chen and Rahman [24] examined the relationship between memorable tourism experiences and loyalty to cultural destinations and revealed that memorable travel experiences exhibit a positive association with loyalty. Zhang, $\mathrm{Wu}$, and Buhalis [58] explored the relationship between a destination's image, memorable travel experiences, and the intention to revisit among Korean tourists in Huangshan City, China. The results showed that memorable tourism experiences positively influenced the intentions to revisit. Therefore, the following hypothesis was proposed and all hypotheses are presented in Figure 1:

Hypotheses 8 (H8). The sense of reliving has a positive effect on loyalty. 


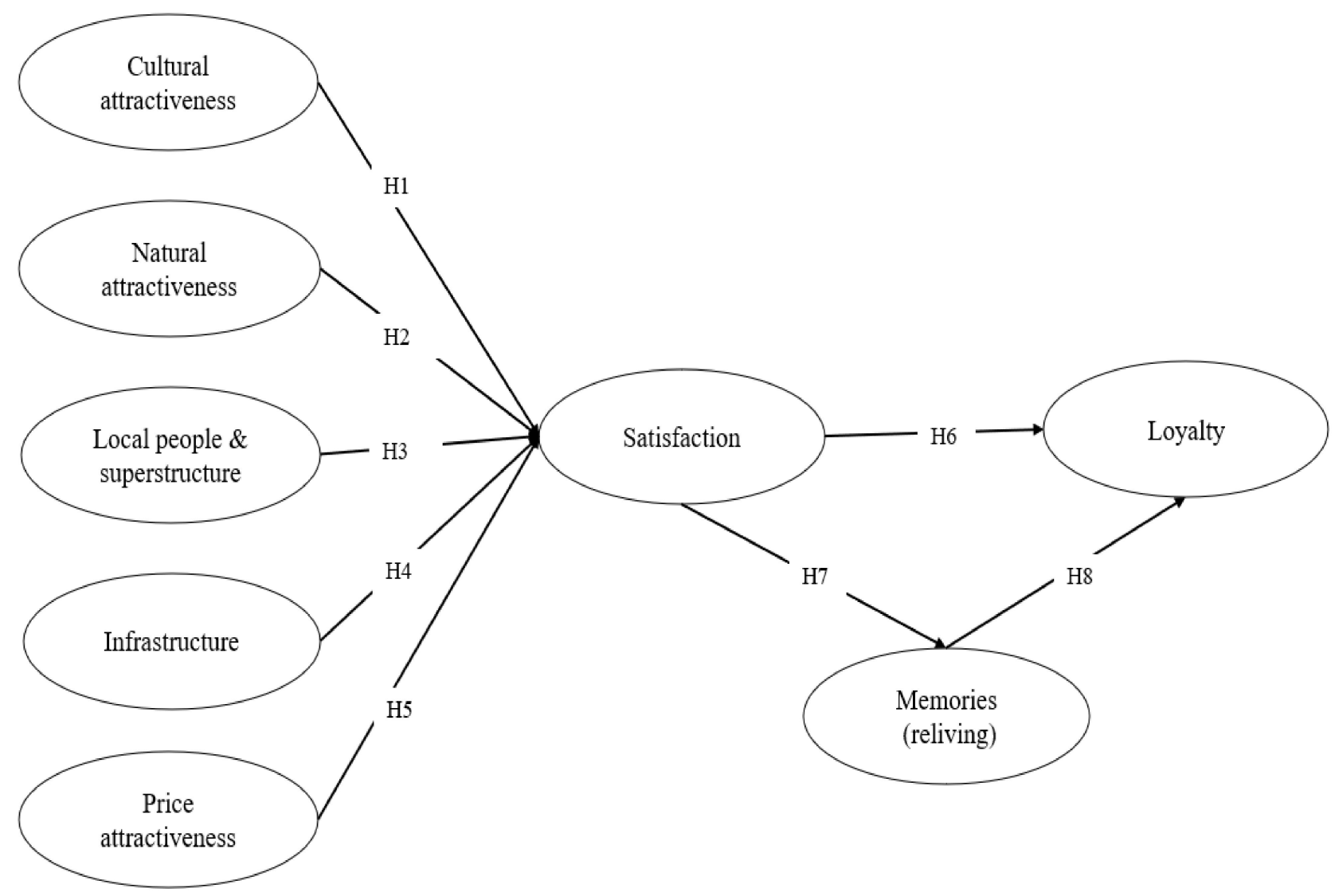

Figure 1. The proposed model.

\section{Methods}

\subsection{Research Setting}

In 2019, Uzbekistan's population was approximately 33.6 million, its gross domestic product (GDP) was USD 57.92 billion, and its GDP growth was 5.6\% [59]. As the government aims to boost the economy, tourism has become one of the most important industry sectors for improving the system and infrastructure of tourism industries, creating a destination brand image and facilitating international cooperation [5]. The number of inbound tourists to Uzbekistan increased substantially from 2.07 million in 2016 to 5.3 million in 2018. The increase from 2.69 million in 2017 to 5.3 million in 2018 shows that the number of tourists in the country doubled in this period [60]. In 2018, the majority of international tourists (86.1\%) came from Central Asian countries [60]. Moreover, other countries, such as Russia, Germany, Turkey, the United States, India, and South Korea, comprised the international tourism market $[1,60]$.

This substantial growth in tourism may be due to the government's reform of the tourism system (e.g., visas, transportation, travel-related facilities, and intermediaries) and the promotion of tourism to create jobs, facilitate business opportunities, and improve the country's image [60]. The UNESCO WHL is well-recognized in Uzbekistan, as the country has five UNESCO World Heritage sites, namely, the Historic Center of Bukhara, the Historic Center of Shakhrisyabz, Itchan Kala, and the crossroads of cultures in Samarkand in cultural resources and Western Tien-Shan in natural resources [61]. Destination marketing organizations (DMOs) and private sectors in Uzbekistan have paid considerable attention to Silk Road tourism, owing to its excellent reputation as a unique cultural and natural attraction and increased interest among domestic and international tourists [62]. Moreover, famous ancient Silk Road cities in Uzbekistan have relatively well-established infrastructure and transportation and demonstrate destination attractiveness [6]. As the Uzbekistan government strives to revive Silk Road tourism, attract foreign investments, and increase 
international cooperation in hospitality and tourism, developing Silk Road tourism can be considered a prioritized tourism policy at both a regional and national level $[6,62]$.

\subsection{Measures}

The questionnaire developed for this study consisted of three sections. The first section included travel characteristics, and the second section included items on destination attractiveness, satisfaction, the sense of reliving, and loyalty. The constructs were employed to examine the proposed model, as presented in Table 1.

Table 1. The results of confirmatory factor analysis.

\begin{tabular}{|c|c|c|c|}
\hline & Item & Item Source & Standardized Loading \\
\hline \multirow{5}{*}{ Cultural } & \multicolumn{2}{|l|}{ Historic/heritage sites and museums } & 0.76 \\
\hline & Artistic/architectural features & & 0.76 \\
\hline & Unique local architectures and buildings & {$[31,34,41,60,61,63,64]$} & 0.74 \\
\hline & \multicolumn{2}{|l|}{$\begin{array}{l}\text { Traditional performing arts (dancing, } \\
\text { music) }\end{array}$} & 0.72 \\
\hline & \multicolumn{2}{|l|}{ Traditional rituals } & 0.64 \\
\hline \multirow{3}{*}{ Natural } & \multirow{3}{*}{$\begin{array}{l}\text { Biodiversity of plants and animals } \\
\text { National parks/nature scenery } \\
\text { Pleasant climate and good natural } \\
\text { environment }\end{array}$} & & 0.75 \\
\hline & & & 0.75 \\
\hline & & & 0.74 \\
\hline \multirow{4}{*}{ Superstructure } & & 0.77 \\
\hline & \multicolumn{2}{|l|}{$\begin{array}{l}\text { Ease of communication between tourists } \\
\text { and residents }\end{array}$} & 0.71 \\
\hline & \multicolumn{2}{|l|}{ Hotels and accommodation facilities } & 0.76 \\
\hline & \multicolumn{2}{|l|}{ Number of restaurants and local cuisine } & 0.68 \\
\hline \multirow{2}{*}{ Infrastructure } & & 0.73 \\
\hline & \multicolumn{2}{|l|}{$\begin{array}{l}\text { Financial institutions and currency } \\
\text { exchange facilities }\end{array}$} & 0.73 \\
\hline \multirow{2}{*}{ Price } & \multirow{2}{*}{\multicolumn{2}{|c|}{$\begin{array}{l}\text { Competitive price of the destination } \\
\text { Reasonable price level }\end{array}$}} & 0.74 \\
\hline & & & 0.82 \\
\hline \multirow{5}{*}{ Satisfaction } & \multirow{5}{*}{\multicolumn{2}{|c|}{$\begin{array}{l}\text { Overall, I am pleased with my decision } \\
\text { to visit the cultural heritage in } \\
\text { Uzbekistan. } \\
\text { My overall experience toward visiting } \\
\text { Uzbekistan's cultural heritage is } \\
\text { satisfied. } \\
\text { The visit to this destination exceeded my } \\
\text { expectations. }\end{array}$}} & 0.81 \\
\hline & & & \\
\hline & & & \\
\hline & & & 0.85 \\
\hline & & & 0.74 \\
\hline \multirow{3}{*}{ Sense of Reliving } & \multirow{3}{*}{\multicolumn{2}{|c|}{$\begin{array}{l}\text { While remembering, it is as if I am living } \\
\text { Uzbekistan travel again. } \\
\text { While remembering, it is as if I am } \\
\text { mentally traveling back to the time and } \\
\text { place of Uzbekistan travel. } \\
\text { While remembering, it is as if I am } \\
\text { experiencing the same feelings, } \\
\text { emotions, and/or atmosphere again. }\end{array}$}} & 0.72 \\
\hline & & & 0.74 \\
\hline & & & 0.73 \\
\hline \multirow{3}{*}{ Loyalty } & $\begin{array}{l}\text { I would tell other people positive things } \\
\text { about Uzbekistan travel. }\end{array}$ & \multirow[t]{3}{*}[50]{} & 0.76 \\
\hline & $\begin{array}{l}\text { I would recommend Uzbekistan travel } \\
\text { to people who seek my advice. }\end{array}$ & & 0.75 \\
\hline & $\begin{array}{l}\text { I would visit Uzbekistan travel again if I } \\
\text { could. }\end{array}$ & & 0.68 \\
\hline
\end{tabular}

The destination attractiveness measurement was adopted from previous research $[31,34,41,60,61,63,64]$. There were 20 items included for assessing destination 
attractiveness dimensions, namely, physical and cultural attractiveness, natural attractiveness, the local people and superstructure, entertainment, infrastructure, and price attractiveness. After the measurement items were tested, a total of 16 items of destination attractiveness items were used. All the items were measured with a five-point Likert-type scale $(1=$ not at all important to $5=$ extremely important).

Satisfaction included three items adopted from Oliver [50] (e.g., "My overall experience in visiting Uzbekistan's cultural heritage sites is satisfying"). The sense of reliving included three items [55] (e.g., "While remembering, it is as if I am experiencing Uzbekistan travel again."), and loyalty included three items [50] (e.g., "I would tell other people positive things about Uzbekistan travel."). Satisfaction, the sense of reliving, and loyalty were measured with a five-point Likert-type scale $(1=$ strongly disagree to $5=$ strongly agree). Finally, the last section collected the respondents' demographic characteristics.

\subsection{Data Collection}

The data were collected from panels in the United States via SurveyMonkey. This study used nonprobability sampling and proportionate sampling based on key demographic characteristics, such as age, gender, income, and residence. The criteria for the respondents were (1) those who had visited Uzbekistan for Silk Road travel, (2) those who had visited in the past five years, and (3) those aged 18 years or older.

A brief introduction to this study was presented in the first online survey. All the survey questions were in English. After the online questionnaire was completed, a pilot test was completed to evaluate the flow of the questionnaire and check for typos and mistakes. The face and content validity and criterion validity were also assessed. The survey link for the pilot test was sent to experts and graduate students. Their feedback and comments were used to revise and refine the survey questionnaire.

The online survey was developed on the SurveyMonkey website, and the respondents received rewards from SurveyMonkey. The survey link was sent to the panels, and a reminder was sent to those who did not participate in the survey. Data collection was conducted from 12 May to 20 May 2020. A total of 482 respondents met the survey criteria and passed the screening questions (i.e., participation in Silk Road tourism in Uzbekistan within the period of 2016-2020). Excluding the incomplete surveys, a total of 477 questionnaires were used.

\subsection{Demographic Characteristics}

The results of the demographic characteristics for this study are presented in Table 2. Regarding gender, the numbers of male $(n=243,50.9 \%)$ and female $(n=234,49.1 \%)$ respondents were nearly equal. The group composed of respondents in their 20s was the largest $(\mathrm{n}=161,33.8 \%)$, followed by the groups with respondents in their $30 \mathrm{~s}(\mathrm{n}=123$, $25.8 \%), 40 \mathrm{~s}(\mathrm{n}=95,19.9 \%)$, and $50 \mathrm{~s}(\mathrm{n}=64,13.4 \%)$. The group consisting of respondents aged 60 years or older $(\mathrm{n}=34,7.1 \%)$ was the smallest. Approximately $37.9 \%$ of the survey respondents $(n=181)$ had a bachelor's degree. The group consisting of high school graduates $(n=111,23.3 \%$ ) was the second largest group, followed by the groups composed of respondents with an associate degree $(\mathrm{n}=101,21.2 \%)$ and postgraduate degree $(\mathrm{n}=84,17.6 \%)$. Approximately $49.9 \%$ of the respondents were married, and $45.7 \%$ were single. Regarding household income, approximately $20.1 \%$ of the respondents had incomes between USD 40,000 and less than USD 60,000, followed by those with incomes between USD 60,000 and 80,000 ( $\mathrm{n}=93,19.5 \%)$. 
Table 2. Demographic characteristics.

\begin{tabular}{|c|c|c|c|}
\hline Variable & Category & $\mathbf{n}$ & $\%$ \\
\hline \multirow{2}{*}{ Gender } & Male & 243 & 50.9 \\
\hline & Female & 234 & 49.1 \\
\hline \multirow{5}{*}{ Age $(\mathrm{M}=37)$} & 18-29 years old & 161 & 33.8 \\
\hline & 30-39 years old & 123 & 25.8 \\
\hline & 40-49 years old & 95 & 19.9 \\
\hline & $50-59$ years old & 64 & 13.4 \\
\hline & Over 60 years old & 34 & 7.1 \\
\hline \multirow{4}{*}{ Education } & High school & 111 & 23.3 \\
\hline & Associate degree & 101 & 21.2 \\
\hline & Bachelor's degree & 181 & 37.9 \\
\hline & Postgraduate degree & 84 & 17.6 \\
\hline \multirow{3}{*}{ Marital status } & Single & 218 & 45.7 \\
\hline & Married & 238 & 49.9 \\
\hline & Other & 21 & 4.4 \\
\hline \multirow{8}{*}{$\begin{array}{l}\text { Annual household } \\
\text { income (USD) }\end{array}$} & Under 20,000 & 37 & 9.9 \\
\hline & 20,000 -less than 40,000 & 63 & 13.2 \\
\hline & 40,000 - less than 60,000 & 96 & 20.1 \\
\hline & 60,000 -less than 80,000 & 93 & 19.5 \\
\hline & 80,000 - less than 100,000 & 61 & 12.8 \\
\hline & 100,000 -less than 120,000 & 45 & 9.4 \\
\hline & 120,000 -less than 150,000 & 32 & 6.7 \\
\hline & Over $150,000,000$ & 40 & 8.4 \\
\hline
\end{tabular}

Note: USD = United States Dollar.

\section{Results}

\subsection{Confirmatory Factor Analysis (CFA)}

The hypotheses were tested by employing a two-stage approach [65]. First, exploratory factor analysis was conducted to identify the latent constructs of the items of Silk Road travel attractiveness. Second, CFA was performed to confirm the dimensions of the proposed model and evaluate their validity and reliability. Several model-fit criteria were confirmed, and a structural equation model (SEM) was constructed to test the association between the hypotheses. Stata 16 was used for the analyses. The CFA results in Table 3 show standardized loadings ranging from 0.64 to 0.85 . The overall model fit of the CFA results was statistically acceptable: $\chi^{2}(247)=481.140, p<0.001, \chi^{2} / d f=1.948$, goodness of fit index $(\mathrm{GFI})=0.926$, comparative fit index $(\mathrm{CFI})=0.962$, Tucker-Lewis index $(\mathrm{TLI})=0.954$, root mean square error of approximation (RMSEA) $=0.045$, and standardized root mean squared residual $(S R M R)=0.030$. The overall model fit indicated satisfactory fit indices $[66,67]$. The composite reliability of the eight constructs ranged from 0.700 to 0.846 . All the constructs exceeded 0.7 , which is the recommended threshold and indicates convergent validity $[68,69]$. Therefore, internal consistency was confirmed. All the constructs had average variance extracted (AVE) values above 0.5 , which is the recommended threshold [70]. As shown in Table 3, the squared correlations are all below the AVE values and confirm the discriminant validity. 
Table 3. Summary of the confirmatory factor analysis (CFA) results.

\begin{tabular}{|c|c|c|c|c|c|c|c|c|c|c|c|}
\hline & No. of Items & Mean (Std. Dev.) & AVE & Cultural & Natural & Superstructure & Infrastructure & Price & Satisfaction & $\begin{array}{l}\text { Sense of } \\
\text { Reliving }\end{array}$ & Loyalty \\
\hline Cultural & 5 & $3.439(0.877)$ & 0.526 & $0.846^{\mathrm{a}}$ & $0.645^{b}$ & 0.629 & 0.496 & 0.447 & 0.505 & 0.374 & 0.433 \\
\hline Natural & 3 & $3.555(0.926)$ & 0.558 & $0.416^{\mathrm{c}}$ & 0.789 & 0.659 & 0.535 & 0.464 & 0.468 & 0.373 & 0.381 \\
\hline Superstructure & 4 & $3.652(0.865)$ & 0.534 & 0.396 & 0.434 & 0.822 & 0.583 & 0.534 & 0.530 & 0.392 & 0.459 \\
\hline Infrastructure & 2 & $3.730(0.936)$ & 0.533 & 0.246 & 0.286 & 0.340 & 0.700 & 0.460 & 0.434 & 0.344 & 0.394 \\
\hline Price & 2 & $3.730(0.936)$ & 0.610 & 0.200 & 0.215 & 0.285 & 0.212 & 0.744 & 0.399 & 0.329 & 0.353 \\
\hline Satisfaction & 3 & $3.816(0.857)$ & 0.642 & 0.255 & 0.219 & 0.281 & 0.188 & 0.159 & 0.842 & 0.509 & 0.575 \\
\hline Sense of reliving & 3 & $3.624(0.815)$ & 0.533 & 0.140 & 0.139 & 0.154 & 0.118 & 0.108 & 0.259 & 0.773 & 0.472 \\
\hline
\end{tabular}

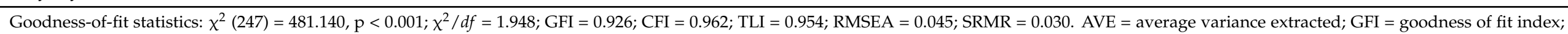

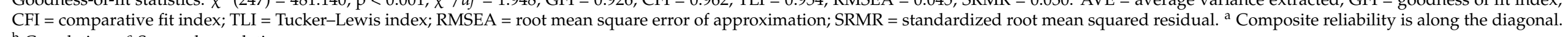

${ }^{\mathrm{b}}$ Correlations. ${ }^{\mathrm{c}}$ Squared correlations. 


\subsection{Structural Model}

A SEM was constructed to test the proposed model, and the results are presented in Table 4 and Figure 2. The fit indices show that the model demonstrates a good model fit to the data $\left(\chi^{2}=495.167, d f=257, \chi^{2} / d f=1.927, \mathrm{GFI}=0.924, \mathrm{CFI}=0.962, \mathrm{TLI}=0.955\right.$, RMSEA $=0.044$, and SRMR $=0.032 ;$ Byrne, 1998 and 2001). The results show that cultural attractiveness $(\beta=0.336, p<0.001)$ and superstructure attractiveness $(\beta=0.293, p<0.05)$ were significantly related to satisfaction. However, natural attractiveness $(\beta=-0.153$, $p=0.271)$, infrastructure attractiveness $(\beta=0.231, p=0.115)$, and price attractiveness $(\beta=0.119, p=0.227)$ were not significantly associated with satisfaction. Satisfaction $(\beta=0.728, p<0.001)$ was significantly related to the sense of reliving. Moreover, satisfaction ( $\beta=0.571, p<0.001)$ was significantly related to loyalty, and the sense of reliving $(\beta=0.339$, $p<0.01$ ) was significantly associated with loyalty. Furthermore, satisfaction was positively related to loyalty and mediated by the sense of reliving. As a result, $\mathrm{H} 1$ and $\mathrm{H} 3$ were supported, but H2, H4, and $\mathrm{H} 5$ were not supported. Moreover, H6, H7, and H8 were, likewise, supported. The results highlight the mediating role of the sense of reliving. The mediating effects were determined and are presented in Table 4. Satisfaction and the sense of reliving mediate the relationship between destination attractiveness and loyalty.

Table 4. The structural equation model (SEM) results.

\begin{tabular}{lclcccc}
\hline & & & & Coefficient & $\mathbf{z}$ & Hypothesis \\
\hline H1 & Cultural & $\rightarrow$ & Satisfaction & $0.336^{* * *}$ & 3.31 & Supported \\
H2 & Natural & $\rightarrow$ & Satisfaction & -0.153 & -1.10 & Not supported \\
H3 & Superstructure & $\rightarrow$ & Satisfaction & $0.293^{*}$ & 2.00 & Supported \\
H4 & Infrastructure & $\rightarrow$ & Satisfaction & 0.231 & 1.58 & Not supported \\
H5 & Price & $\rightarrow$ & Satisfaction & 0.119 & 1.21 & Not supported \\
H6 & Satisfaction & $\rightarrow$ & Reliving & $0.728^{* * *}$ & 14.11 & Supported \\
H7 & Satisfaction & $\rightarrow$ & Loyalty & $0.571^{* * *}$ & 6.53 & Supported \\
H8 & Reliving & $\rightarrow$ & Loyalty & $0.339^{* *}$ & 3.44 & Supported \\
\hline Note** & $\rightarrow=05^{* *} p=<0.1^{* * *} p=<0.001$ & & &
\end{tabular}

Note: ${ }^{*} p=<0.05,{ }^{* *} p=<0.01,{ }^{* * *} p=<0.001$.

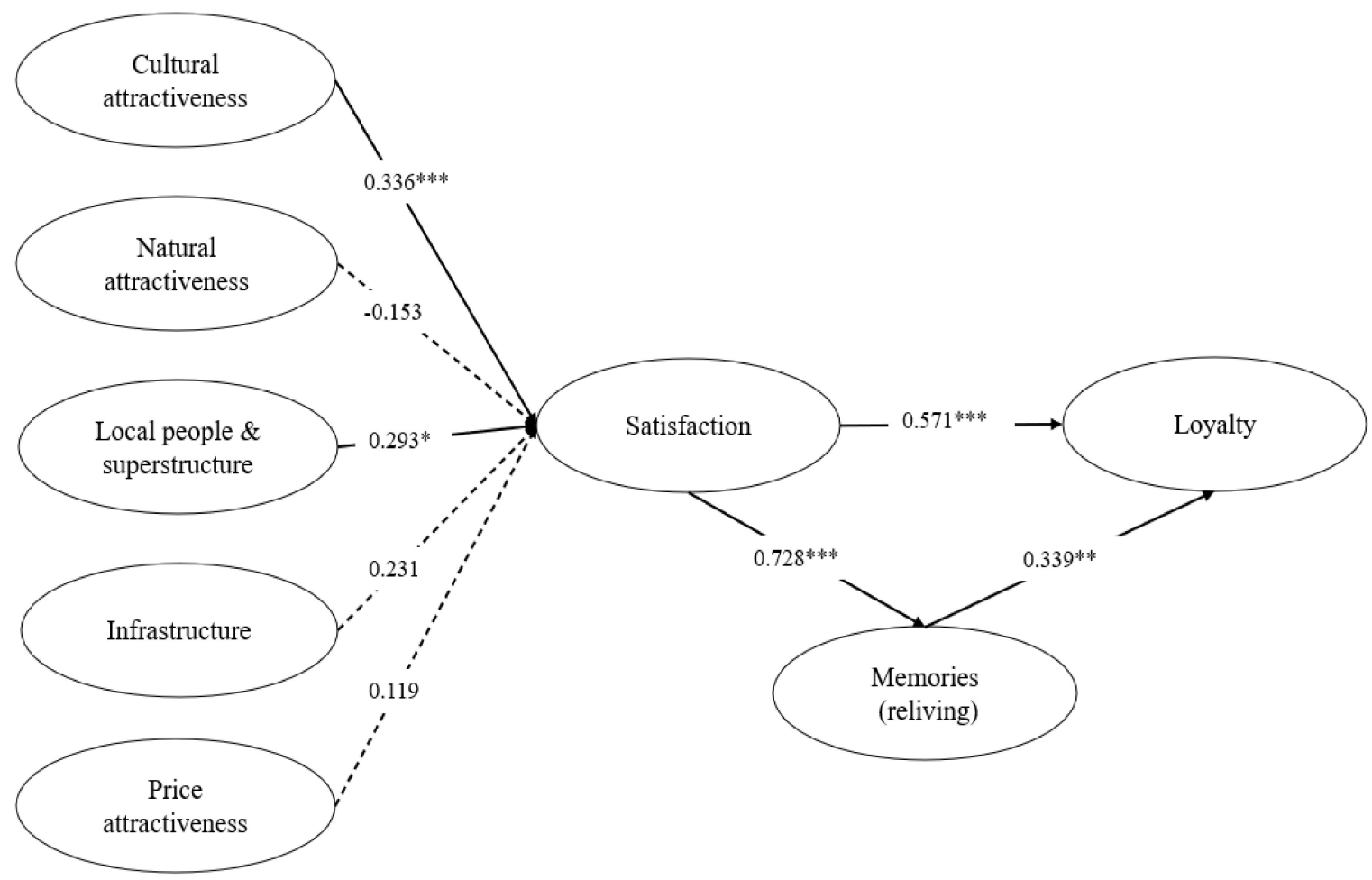

Figure 2. The results of the proposed model. Note: ${ }^{*} p=<0.05,{ }^{* *} p=<0.01,{ }^{* * *} p=<0.001$. 


\section{Discussion and Conclusion}

\subsection{Theoretical Implications}

The present study examined the relationship between destination attractiveness and satisfaction, the sense of reliving, and loyalty among American tourists who participated in Silk Road tourism in Uzbekistan. This empirical research shows that destination attractiveness has a positive association with satisfaction. This study also demonstrates a positive relationship with satisfaction and loyalty, which is mediated by the sense of reliving.

The present study suggests several theoretical implications. First, the results show that destination attractiveness is positively related to satisfaction. Destination attractiveness consists of five constructs, namely, cultural attractiveness, natural attractiveness, the local people and superstructure, infrastructure, and price attractiveness. Among the five destination attractiveness constructs, cultural attractiveness is the most influential factor, followed by the local people and superstructure. Consistent with previous research $[6-8,11]$, cultural attractiveness, the warm hospitality of local people, and the superstructure, such as accommodation, are competitive attributes of Silk Road tourism in Uzbekistan. However, three destination attractiveness constructs (i.e., natural attractiveness, infrastructure, and price attractiveness) do not have a significant association with satisfaction. The insignificant effects of the destination attractiveness dimensions on satisfaction may be because the factors do not fulfill tourists' needs and desires. The results indicate that the destination attractiveness dimensions may not all be equally important and positively influence tourist satisfaction.

Second, the results confirm that satisfaction increases tourist loyalty. Consistent with previous research [13-15], tourist satisfaction increases loyalty for Silk Road tourism. The results reveal that highly satisfied tourists are inclined to share their travel stories and demonstrate intentions to revisit Silk Road sites in Uzbekistan.

Finally, a mediating role of the sense of reliving with regard to satisfaction and loyalty is observable. This study empirically demonstrates the role of memorable travel experiences, consistent with previous research [30]. Unlike previous research on memorable travel experiences, this study focused on tourists' relived travel experiences after experiencing Silk Road tourism. Moreover, this study proposes destination attractiveness as an antecedent of memorable travel experiences $[19,21,22]$. The results suggest that destination attractiveness includes multidimensional constructs and can provide a deep understanding of destination attractiveness and memorable experiences for increasing loyalty to tourism destinations in the context of Silk Road tourism in Uzbekistan.

\subsection{Practical Implications}

This study suggests several practical implications. First, this study included five destination attractiveness constructs in the proposed model. Cultural attractiveness, the local people, and the superstructure are the most influential destination attractiveness constructs affecting tourist satisfaction. Tourists can be enticed by the intangible and tangible cultural attractiveness of Silk Road tourism. Practitioners and DMOs should create rich storytelling content and provide engaging experiential programs wherein tourists can learn about cultural attractiveness, such as cultural and historical architecture, buildings, museums, tangible crafts, and intangible arts. Moreover, the local people and superstructure are important for destination attractiveness. The warm hospitality and friendliness of local people toward tourists in the main cities in Silk Road tourism appear to increase overall tourist satisfaction. Moreover, the superstructure (e.g., unique interiors of local homestays, hotels, and restaurants) increases satisfaction among tourists. Practitioners should seek ways to facilitate interactions between tourists and the local people and encourage tourists to experience the local superstructure.

Second, this study shows that three destination attractiveness constructs, namely, natural attractiveness, infrastructure, and price attractiveness, do not have a significant influence on satisfaction. These attractiveness constructs may not perform beyond tourist expectations and meet tourists' needs and desires. For example, tourists may experience 
difficulties visiting national parks for their natural attractiveness owing to a lack of information and thus spend more time around core cultural and historical buildings and museums. Moreover, tourists planning to visit several Silk Road destinations could not find transitions between destinations in terms of time schedules, available transportation, and terminals. Practitioners should monitor and improve the performance of such constructs for tourists and maintain the quality of destination attractiveness without variation. Finally, practitioners should monitor price policies for tourists and provide promotions or regulate prices at destinations during peak and off-peak seasons.

Finally, the results confirm the mediating role of the sense of reliving with regard to satisfaction and loyalty. Regarding the sense of reliving, tourists remember their travel experiences upon returning home. Practitioners should develop memorable souvenirs or traditional products that can trigger travel experience memories. Moreover, satisfied tourists are likely to relive their travel experiences and demonstrate revisit intentions. Therefore, managers and practitioners should create photo zones where tourists can take photos and/or videos to record and display memorable moments in photobooks or on social media platforms.

\subsection{Limitations and Recommendations for Future Research}

Although this study provides important theoretical and practical implications based on empirical evidence, it has several limitations. First, the findings should not be overgeneralized, and future research needs to be able to replicate them with tourist groups. Second, this study examined the destination competitiveness of major cities along the Silk Road in Uzbekistan, as cultural and heritage legacies and resources can be found in nearby countries (e.g., countries in Eastern Europe and China). Crosscultural comparative research can provide a deep understanding of Silk Road tourism. Finally, the research data were collected at one point in time and cannot suggest changes in destination competitiveness and tourists' reactions after experiencing Silk Road tourism. Therefore, future research should use different methodologies or a longitudinal method.

Author Contributions: Conceptualization, M.R., H.J., and Y.-j.A.; methodology, Y.-j.A.; formal analysis, Y.-j.A.; data curation, Y.-j.A.; writing-original draft preparation, M.R., H.J., and Y.-j.A.; writing-review and editing, Y.-j.A.; supervision, Y.-j.A. All authors have read and agreed to the published version of the manuscript.

Funding: This research received no external funding.

Institutional Review Board Statement: Not applicable.

Informed Consent Statement: Not applicable.

Data Availability Statement: Not applicable.

Conflicts of Interest: The authors declare no conflict of interest.

\section{References}

1. WTO. New UNWTO Silk Road Action Plan 2014. Available online: https://www.unwto.org/archive/global/news/2014--07--03 /new-unwto-silk-road-action-plan-20142015-now-available (accessed on 30 January 2021).

2. UNWTO. Uzbekistan Tourism Insight. Available online: https://www.unwto.org/archive/global/publication/uzbekistantourism-insight (accessed on 30 January 2021).

3. UNESCO World Heritage. Consultation Meeting on the Application of the UNESCO HUL Recommendation at the World Heritage Properties in Uzbekistan. Available online: https:/ / whc.unesco.org/en/events/1336/ (accessed on 5 January 2021).

4. Bak, S.; Min, C.-K.; Roh, T.-S. Impacts of UNESCO-Listed Tangible and Intangible Heritages on Tourism. J. Travel Tour. Mark. 2019, 36, 917-927. [CrossRef]

5. CPS. Tourism Development in Uzbekistan: Challenges and Opportunities. Available online: https://www.google.com/ search?q=a+number+of+american+tourists+uzbekistan+tourism\&sxsrf=ALeKk03vb8PMW09pzEG7dbA92nVaz5agCg: 1609819429520\&ei=JeXzX9KKH4znwQPvrJmwCQ\&start=10\&sa=N\&ved=2ahUKEwiSsf7Z9IPuAhWMc3AKHW9WBpYQ8 tMDegQIFBA2\&biw=1279\&bih=854 (accessed on 5 January 2021). 
6. González, R.C.L.; Araujo, M.L.D.R.; Kim, A. The Potential Attractiveness of Uzbekistan. Designing Strategies to Promote the Central Asia Republic by Analysing Official Tourism Image and Conducting at-Destination Surveys. J. Tour. Anal. Rev. Análisis Tur. JTA 2016, 22, 12-27. [CrossRef]

7. Kantarci, K. Perceptions of Foreign Investors on the Tourism Market in Central Asia Including Kyrgyzstan, Kazakhstan, Uzbekistan, Turkmenistan. Tour. Manag. 2007, 28, 820-829. [CrossRef]

8. Kantarci, K. Perceptions of Central Asia Travel Conditions: Kyrgyzstan, Kazakhstan, Uzbekistan, and Turkmenistan. J. Hosp. Leis. Mark. 2007, 15, 55-71. [CrossRef]

9. Patterson, I.; Turaev, H. Gastonomy Tourism as an Emerging Niche Market in Uzbekistan. J. Gastron. Hosp. Travel 2020, 3, 141-149.

10. Saidmamatov, O.; Matyakubov, U.; Rudenko, I.; Filimonau, V.; Day, J.; Luthe, T. Employing Ecotourism Opportunities for Sustainability in the Aral Sea Region: Prospects and Challenges. Sustainability 2020, 12, 9249. [CrossRef]

11. Fayzullaev, K.; Cassel, S.H.; Brandt, D. Destination Image in Uzbekistan-Heritage of the Silk Road and Nature Experience as the Core of an Evolving Post Soviet Identity. Serv. Ind. J. 2018, 1-16. [CrossRef]

12. Gunn, C.A. Vacationscape: Developing Tourist Areas. Available online: https://www.amazon.com/Vacationscape-DevelopingTourist-Clare-Gunn/dp/1560325194 (accessed on 30 January 2021).

13. Fuchs, M.; Weiermair, K. New Perspectives of Satisfaction Research in Tourism Destinations. Tour. Rev. 2003, 58, 6-14. [CrossRef]

14. Kozak, M.; Rimmington, M. Tourist Satisfaction with Mallorca, Spain, as an Off-Season Holiday Destination. J. Travel Res. 2000, 38, 260-269. [CrossRef]

15. Owusu-Frimpong, N.; Nwankwo, S.; Blankson, C.; Tarnanidis, T. The Effect of Service Quality and Satisfaction on Destination Attractiveness of Sub-Saharan African Countries: The Case of Ghana. Curr. Issues Tour. 2013, 16, 627-646. [CrossRef]

16. Zeithaml, V.A.; Berry, L.L.; Parasuraman, A. The Behavioral Consequences of Service Quality. J. Mark. 1996, 60, 31-46. [CrossRef]

17. Kim, D.; Perdue, R.R. The Influence of Image on Destination Attractiveness. J. Travel Tour. Mark. 2011, 28, 225-239. [CrossRef]

18. Buhalis, D. Marketing the Competitive Destination of the Future. Tour. Manag. 2000, 21, 97-116. [CrossRef]

19. Hu, Y.; Ritchie, J.R.B. Measuring Destination Attractiveness: A Contextual Approach. J. Travel Res. 1993, 32, 25-34. [CrossRef]

20. Kim, H. Perceived Attractiveness of Korean Destinations. Ann. Tour. Res. 1998, 25, 340-361. [CrossRef]

21. Kim, J.-H. The Antecedents of Memorable Tourism Experiences: The Development of a Scale to Measure the Destination Attributes Associated with Memorable Experiences. Tour. Manag. 2014, 44, 34-45. [CrossRef]

22. Kim, J.-H. The Impact of Memorable Tourism Experiences on Loyalty Behaviors: The Mediating Effects of Destination Image and Satisfaction. J. Travel Res. 2018, 57, 856-870. [CrossRef]

23. Ahn, Y.; Hyun, S.S.; Kim, I. Vivid-Memory Formation through Experiential Value in the Context of the International Industrial Exhibition. J. Travel Tour. Mark. 2017, 34, 291-311. [CrossRef]

24. Chen, H.; Rahman, I. Cultural Tourism: An Analysis of Engagement, Cultural Contact, Memorable Tourism Experience and Destination Loyalty. Tour. Manag. Perspect. 2018, 26, 153-163. [CrossRef]

25. Ittamalla, R.; Kumar, D.V.S. Role of Service Experience on Vivid Memory and Loyalty. Int. J. Hosp. Tour. Adm. 2019, 1-23. [CrossRef]

26. Manthiou, A.; Lee, S.; Tang, L.; Chiang, L. The Experience Economy Approach to Festival Marketing: Vivid Memory and Attendee Loyalty. J. Serv. Mark. 2014, 28, 22-35. [CrossRef]

27. Manthiou, A.; Kang, J.; Chiang, L.; Tang, L.R. Investigating the Effects of Memorable Experiences: An Extended Model of Script Theory. J. Travel Tour. Mark. 2016, 33, 362-379. [CrossRef]

28. Quadri-Felitti, D.L.; Fiore, A.M. Destination Loyalty: Effects of Wine Tourists' Experiences, Memories, and Satisfaction on Intentions. Tour. Hosp. Res. 2013, 13, 47-62. [CrossRef]

29. Tung, V.W.S.; Ritchie, J.R.B. Exploring the Essence of Memorable Tourism Experiences. Ann. Tour. Res. 2011, 38, 1367-1386. [CrossRef]

30. Yin, C.-Y.; Poon, P.; Su, J.-L. Yesterday Once More? Autobiographical Memory Evocation Effects on Tourists' Post-Travel Purchase Intentions toward Destination Products. Tour. Manag. 2017, 61, 263-274. [CrossRef]

31. Dwyer, L.; Kim, C. Destination Competitiveness: Determinants and Indicators. Curr. Issues Tour. 2003, 6, 369-414. [CrossRef]

32. Porter, M.E. Competitive Strategy: Techniques for Analyzing Industries and Competitors, Illustrated edition; Free Press: New York, NY, USA, 1998.

33. Formica, S.; Uysal, M. Destination Attractiveness Based on Supply and Demand Evaluations: An Analytical Framework. J. Travel Res. 2006, 44, 418-430. [CrossRef]

34. An, L.T.; Markowski, J.; Bartos, M.; Rzenca, A.; Namiecinski, P. An Evaluation of Destination Attractiveness for Nature-Based Tourism: Recommendations for the Management of National Parks in Vietnam. Nat. Conserv. 2019, 32, 51-80. [CrossRef]

35. WEF. World Economic Forum Annual Meeting Davos. Available online: https://www.weforum.org/events/world-economicforum-annual-meeting-2020/ (accessed on 30 January 2021).

36. Boivin, M.; Tanguay, G.A. Analysis of the Determinants of Urban Tourism Attractiveness: The Case of Québec City and Bordeaux. J. Destin. Mark. Manag. 2019, 11, 67-79. [CrossRef]

37. Bonn, M.A.; Cho, M.; Lee, J.J.; Kim, J.H. A Multilevel Analysis of the Effects of Wine Destination Attributes on Travel Constraints and Revisit Intention. Int. J. Contemp. Hosp. Manag. 2016, 28, 2399-2421. [CrossRef]

38. Cracolici, M.F.; Nijkamp, P. The Attractiveness and Competitiveness of Tourist Destinations: A Study of Southern Italian Regions. Tour. Manag. 2009, 30, 336-344. [CrossRef] 
39. Crouch, G.I. Destination Competitiveness: An Analysis of Determinant Attributes. J. Travel Res. 2011, 50, 27-45. [CrossRef]

40. Enright, M.J.; Newton, J. Determinants of Tourism Destination Competitiveness in Asia Pacific: Comprehensiveness and Universality. J. Travel Res. 2005, 43, 339-350. [CrossRef]

41. Hou, J.-S.; Lin, C.-H.; Morais, D.B. Antecedents of Attachment to a Cultural Tourism Destination: The Case of Hakka and Non-Hakka Taiwanese Visitors to Pei-Pu, Taiwan. J. Travel Res. 2005, 44, 221-233. [CrossRef]

42. Kozak, M. Comparative Assessment of Tourist Satisfaction with Destinations across Two Nationalities. Tour. Manag. 2001, 22, 391-401. [CrossRef]

43. Ahn, Y.; Lee, S.-K.; Lee, S.-M. Do Some Travel Purposes Lead to More Tourist Expenditure Patterns than Others? Evidence from an Almost Ideal Demand System (AIDS) Analysis. Asia Pac. J. Tour. Res. 2020, 25, 902-913. [CrossRef]

44. Chi, X.; Lee, S.K.; Ahn, Y.; Kiatkawsin, K. Tourist-Perceived Quality and Loyalty Intentions towards Rural Tourism in China. Sustainability 2020, 12, 3614. [CrossRef]

45. Medina-Muñoz, D.R.; Medina-Muñoz, R.D. The Attractiveness of Wellness Destinations: An Importance-PerformanceSatisfaction Approach. Int. J. Tour. Res. 2014, 16, 521-533. [CrossRef]

46. Mikulić, J.; Krešić, D.; Miličević, K.; Šerić, M.; Ćurković, B. Destination Attractiveness Drivers among Urban Hostel Tourists: An Analysis of Frustrators and Delighters. Int. J. Tour. Res. 2016, 18, 74-81. [CrossRef]

47. Ahn, Y.-J. Recruitment of Volunteers Connected with Sports Mega-Events: A Case Study of the PyeongChang 2018 Olympic and Paralympic Winter Games. J. Destin. Mark. Manag. 2018, 8, 194-203. [CrossRef]

48. Oliver, R.L. A Cognitive Model of the Antecedents and Consequences of Satisfaction Decisions. J. Mark. Res. 1980, 17, 460-469. [CrossRef]

49. Jeuring, J.H.G.; Haartsen, T. The Challenge of Proximity: The (Un)Attractiveness of near-Home Tourism Destinations. Tour. Geogr. 2017, 19, 118-141. [CrossRef]

50. Oliver, R.L. Satisfaction: A Behavioral Perspective on the Consumer; McGraw Hill: New York, NY, USA, 1997.

51. Parasuraman, A.; Zeithaml, V.A.; Berry, L.L. A Conceptual Model of Service Quality and Its Implications for Future Research. J. Mark. 1985, 49, 41-50. [CrossRef]

52. Kozak, M.; Bigné, E.; Andreu, L. Satisfaction and Destination Loyalty. J. Qual. Assur. Hosp. Tour. 2005, 5, 43-59. [CrossRef]

53. Yolal, M.; Chi, C.G.-Q.; Pesämaa, O. Examine Destination Loyalty of First-Time and Repeat Visitors at All-Inclusive Resorts. Int. J. Contemp. Hosp. Manag. 2017, 29, 1834-1853. [CrossRef]

54. Rubin, D.C.; Dennis, M.F.; Beckham, J.C. Autobiographical Memory for Stressful Events: The Role of Autobiographical Memory in Posttraumatic Stress Disorder. Conscious. Cogn. 2011, 20, 840-856. [CrossRef]

55. Rubin, D.C.; Deffler, S.A.; Umanath, S. Scenes Enable a Sense of Reliving: Implications for Autobiographical Memory. Cognition 2019, 183, 44-56. [CrossRef] [PubMed]

56. Kastenholz, E.; Carneiro, M.J.; Marques, C.P.; Loureiro, S.M.C. The Dimensions of Rural Tourism Experience: Impacts on Arousal, Memory, and Satisfaction. J. Travel Tour. Mark. 2018, 35, 189-201. [CrossRef]

57. Sthapit, E.; Björk, P.; Coudounaris, D.N. Emotions Elicited by Local Food Consumption, Memories, Place Attachment and Behavioural Intentions. Anatolia 2017, 28, 363-380. [CrossRef]

58. Zhang, H.; Wu, Y.; Buhalis, D. A Model of Perceived Image, Memorable Tourism Experiences and Revisit Intention. J. Destin. Mark. Manag. 2018, 8, 326-336. [CrossRef]

59. The World Bank. Uzbekistan. Available online: https:/ / data.worldbank.org/country/uzbekistan (accessed on 5 January 2021).

60. Uzbektourism. Tourism in Uzbekistan. Available online: https://uzbektourism.uz/en (accessed on 5 January 2021).

61. UNESCO. Uzbekistan-UNESCO World Heritage Centre. Available online: https://whc.unesco.org/en/statesparties/uz (accessed on 30 January 2021).

62. Baxtishodovich, B.S.; Suyunovich, T.I.; Kholiqulov, A. The Start-up of Tourism in Central Asia Case of Uzbekistan. World Sci. News 2017, 67, 219-237.

63. Islam, S.; Hossain, M.K.; Noor, M. Determining Drivers of Destination Attractiveness: The Case of Nature-Based Tourism of Bangladesh. Int. J. Mark. Stud. 2017, 9, 10. [CrossRef]

64. Ma, E.; Hsiao, A.; Gao, J. Destination Attractiveness and Travel Intention: The Case of Chinese and Indian Students in Queensland, Australia. Asia Pac. J. Tour. Res. 2018, 23, 200-215. [CrossRef]

65. Anderson, J.C.; Gerbing, D.W. Structural Equation Modeling in Practice: A Review and Recommended Two-Step Approach. Psychol. Bull. 1988, 103, 411-423. [CrossRef]

66. Byrne, B.M. Structural Equation Modeling with Lisrel, Prelis, and Simplis: Basic Concepts, Applications, and Programming, 1st ed.; Psychology Press: Mahwah, NJ, USA, 1998.

67. Byrne, B.M. Structural Equation Modeling With AMOS: Basic Concepts, Applications, and Programming, 2nd ed.; Routledge: New York, NY, USA, 2009.

68. Fornell, C.; Larcker, D.F. Evaluating Structural Equation Models with Unobservable Variables and Measurement Error. J. Mark. Res. 1981, 18, 39-50. [CrossRef]

69. Hair, J.F.; Black, W.C.; Babin, B.J.; Anderson, R.E. Multivariate Data Analysis, 7th ed.; Pearson: Upper Saddle River, NJ, USA, 2009.

70. Bagozzi, R.P.; Yi, Y. On the Evaluation of Structural Equation Models. J. Acad. Mark. Sci. 1988, 16, 74-94. [CrossRef] 